\title{
WEBQUEST: A VIRTUAL TOUR ON THE INTERNET IN NATURAL SCIENCE EDUCATION
}

\author{
Martin Bilek ${ }^{1}$, Pavel Opatrny ${ }^{2}$ \\ ${ }^{I}$ Department of Chemistry, Faculty of Education, University of Hradec Králové, \\ Czech Republic \& Department of Chemistry Faculty of Natural Sciences, \\ Constantine the Philosopher University of Nitra, Slovakia \\ ${ }^{2}$ Department of Teaching Chemistry, Faculty of Natural Sciences, Charles \\ University, Prague, Czech Republic \& Department of Pedagogical Studies, \\ Faculty of Humanities, Tomas Bata University in Zlin, Czech Republic
}

\begin{abstract}
A new model of the Internet support of the project instruction is called the WebQuest. The term of the WebQuest means an expedition supported by information which can be searched on web pages, i.e. "Web discovery expedition". The WebQuest method offers the project oriented instruction with the use of current and authentic materials which are available on the Internet, autonomous and cooperative learning, team and associate work, assignments for students, work in the field of bibliographic search, etc.

In the article there are also presented our proposals of projects for science and technical subject instruction: "Are You Cold? Warm Yourself!" about chemical warmers, "Car of the Future!" about fuel cells and "Superabsorbents - amazing polymers!" about absorption.
\end{abstract}

Key words: WebQuest, Science and Technical Teacher Education, Internet, Project Instruction.

\section{Introduction}

Current changes in society burden and stress any individual much more than several years ago. Man must be able to accept changes, be oriented in them, react to them actively. Losing the stability at work counts among the most striking problems. Working structures with fixed roles are disappearing, man changes not only the job, but even the profession or its field. The society is asking for a flexible, thinking, initiative people, as far as in the unstable, uncertain environment. This is a challenge to today's educational system, especially to teachers and their new roles.

In activities aiming at innovations in the field of science and technical subject education our effort concentrates on the field of increasing teachers' information literacy, and the use of the Internet plays one of the most important roles.

In the framework of the Internet supported introduction we are trying to define six main types of "Lessons supported by the Internet"(Bílek, Zemanová, 2007a, 2007b):

1. Searching for information

a) searching for sources,

b) searching for responses to questions, with the help of information sources,

c) searching for materials to be used in seminar projects.

2. Presentating of information

Teachers use the Internet to present the content during the topic explanation. The materials contain animations, images, short videorecordings, etc.

\section{Computer aided instruction}

Pupils work with a programme available on the Internet (explanation of the new topic, practising, revision, evaluation, etc.).

4. The use of software tools in pupils'creative work

The use of programmes available on-line or downloaded to create various objects (formulas, molecules, installations, text documents, tables, graphs, presentations, etc.). 


\section{Modelling of learning objects and pupils'activities}

a) simulations which replace experimental activities (applets, virtual laboratories),

b) experimental activity simulations before and after the real experiment (applets, models and virtual laboratories).

\section{Experimental activity support}

Measurements made by computer (remote laboratories, remote measurements).

According to different experiences (Nolte, 2005; Opatrný, 2007) it can be said that effectivity of the Internet supported introduction is increasing with the use of an initial offer of checked URLs to solve tasks. It helps both to concentrate on the heart of the topic and motivate to continue searching for information on other web pages. This way complies with current use of Internet applications in the process of introduction which the WebQuest belongs to.

\section{Webquest Educational Environment}

The term of the WebQuest means an expedition searching for information on web pages, i.e. "Web discovery expedition". The conception of the WebQuest appeared in the second half of the 1990s in the USA. In 1995 its authors, Bernie Dodge and Tom March from the San Diego State University, introduced a lesson during which Internet links were used (Nolte, 2005; Opatrný, 2007). The WebQuest method offers the project oriented instruction with the use of current and authentic materials which are available on the Internet, autonomous and cooperative learning, team and associate work, assignments for students, work in the field of bibliographic search, etc. (information is available on http://webquest.cz/, http://www.webquest-forum.de/ or http://webquest.sdsu.edu/). One of the well-known WebQuests "Travelling around the History of Atomic Models" is available on http://www.geocities.com/dlkennen/webquest, another similar project is displayed on http://www.pekinhigh.net/webquest/springborn/index.htm (next examples of excellent projects are e.g. at http://www.hschem.org/Resources/webquest.htm).

These projects aim at pupils and students of different levels and specializations; the above mentioned web pages provide detailed information. Every single topic is presented in the form of posters, requires searching for sources and bibliographic data. The Czech Internet environment provides the portal „Učitelský spomocník“ (Teachers'Help) for the WebQuest users. It was designed by the Department of Information Technology and Technical Education, Faculty of Education, Charles University (see URL (WebQuest..., 2005)). The WebQuest.cz is an application combining databases and a publishing system. Unregistered users are allowed to enter the archive of proposed project units (WebQuests). Registered users may work in two ways: in the author's mode a new WebQuest can be designed and saved, or the content mode when any previously saved project may be tailored to new needs (Opatrný, 2007). There are also presented proposals of projects for science and technical subject instruction, e.g. "Are You Cold? Warm Yourself! "about chemical warmers, "Car of the Future"about fuel cells, "Superabsorbents - amazing polymers"about absorption, etc., which were designed by our departments.

\section{General Structure of Webquests}

Proposals of learning units, usually projects, are structured into six follow-up steps which may be modified according to the content of the lesson. The steps are as follows:

1. Introduction (description of the project) - aims at motivating students to the topic and outlines the content of the WebQuest (practical applications, media presentations, short videorecordings, etc.).

2. List of available tasks and topics - proposals are structured for team or individual 
work, according to the pupil's age, various viewpoints etc.

3. Completing the tasks (projects) - proposes possible roles for team work, methods to complete the task, including presentations of partial results (posters, conferences, brochures, etc.).

4. Information sources - checked, annotative Internet links makes reference to the topic, including professional literature, encyclopaedias, magazines etc.

5. Presentations - gives instructions on how to prepare presentations of the results (see step 3).

6. Evaluation and summary of the results - defines the expected level of the project and the amount of credits (points) which can be gained for completing its single parts. Summarizing the project results and self-evaluation concludes the whole process. The WebQuest.cz also offers the electronic discussion on each project and didactic experience from those teachers who has used the material, etc.

\section{Example of the Webwuest - „Are you cold? Warm yourself! “}

The topic of this WebQuest contains information on products, e.g. "hand warmers", which make some everyday activities easier, help in breaking through health problems, in rehabilitation, sports etc.

The materials which are becoming popular but their structure and content are not known to the users, are of two groups: the reversible warmers and the irreversible ones. The former group contains so called "super-cool gels", the latter one works mostly on the principle of exothermic iron oxidation or exothermic hydratation of some salts, e.g. strong exothermic hydratation of burnt $\mathrm{CaCl}_{2}$ which is used in "drink heaters" called "Caldo Caldo". It is an aluminium bag with a drink, e.g. coffee, placed in a plastic cup. The space between the bag and cup is filled with $\mathrm{CaCl}_{2}$, and water. After activating the heating mechanism, i.e. enabling $\mathrm{CaCl}_{2}$ and water to mix by making holes in the plastic foil, the drink gets hot. The same principle is used with "Freddo Freddo"products which use the strong endothermic reaction of $\mathrm{Na} 2 \mathrm{~S} 2 \mathrm{O} 3$ and water as a cooling mechanism.

The proposal of the project enables pupils to:

- see how to use "chemical warmers" in common life,

- gain information on "chemical warmers" by their self-activity, i.e. the principles they operate on, about the production, availability on the market, their advantages and disadvantages,

- discover principles of chemical warmers in experimental activities,

- improve foreign language knowledge in the process of searching for information (Internet, professional literature, etc.),

- cooperate actively in solving problems,

- $\quad$ prepare a presentation and present final results.

The work on the project is usually divided into three parts: the theoretical, experimental and presentational one (Opatrný, 2007). 


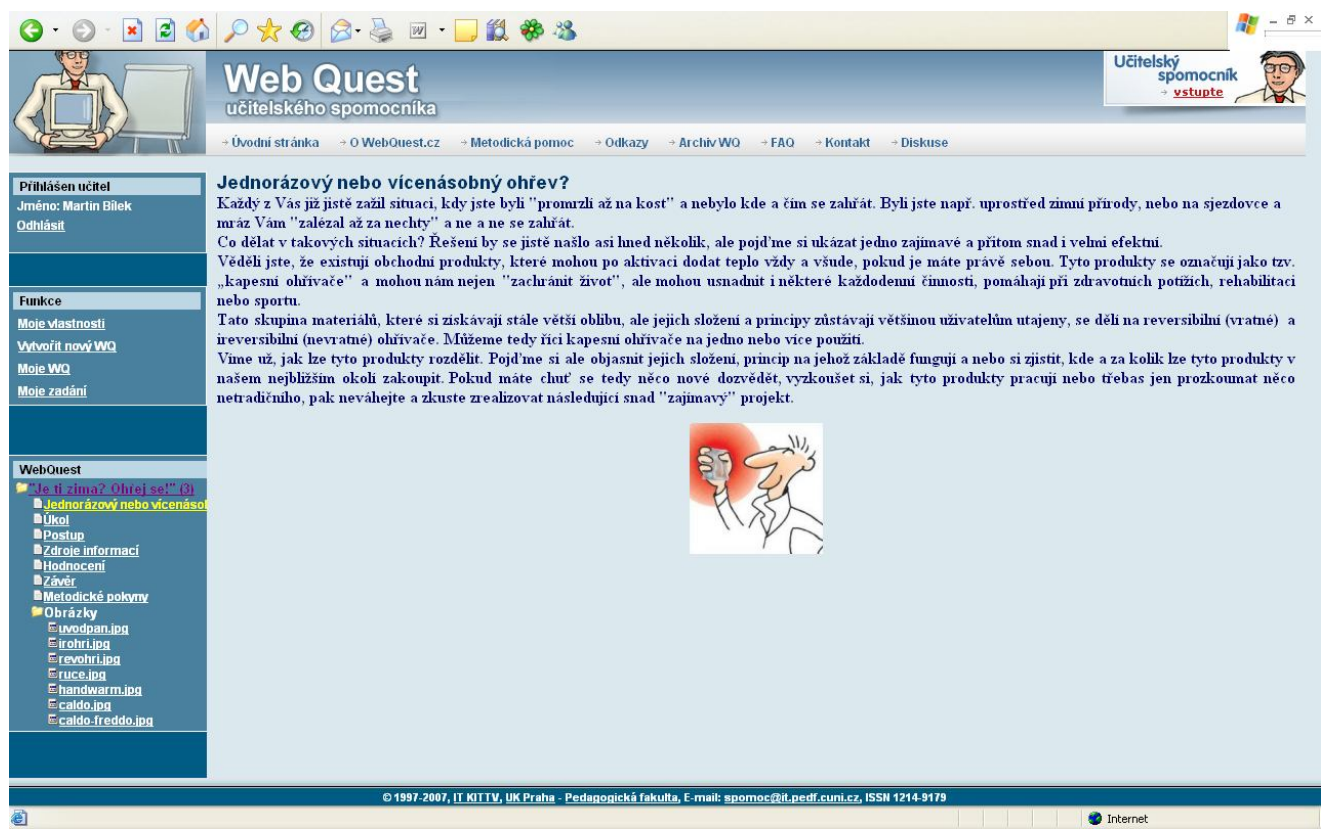

Figure 1. Introductory page of the WebQuest „Are you cold? Warm yourself! “

\section{Example of the Webquest - "Car of the future"}

An outline of the "Car of the Future?" project focuses on usage of interrelations in "alternative sources of energy" branch - fuel cells. It is a co-work of teacher-consultant and groups of pupils who are working with pieces of knowledge of chemistry, physics, biology, geography and informatics. The purpose of the project's realization is an effective web search for the information. The Internet allows the use of foreign languages, mainly German and English. The project focuses on development of students' curiosity, creativity and environmental thinking.

The project aims at:

- introduce the topic of contemporary use of energy and its sources and especially the necessity of changes from the point of so called sustainable development,

- getting information on fuel cells as sources of „pure energy“ via unsupported student's activities,

- innovating laboratory activities with a set demonstrating the principle of fuel cell for grammar school students,

- contributing to mastering critical view on getting information and working with it,

- contributing to integrated science view on new technologies.

In theoretical phase at least one lesson should be devoted to the division students into groups and introduce partial tasks to them. The first groups will evaluate contemporary energetically system and state of our planet from the point of view of classical sources of energy. Necessary information should be gained from libraries, professional magazines and the Internet. Having finished these activities, following questions should be answered: What are contemporary used sources of energy?; How many are they supposed to be in the Earth?; How long is their supposed period of use?; What are the products of combustion?; What is their negative influence on the environment? The second group should try to find information 
concerning alternative sources of energy from the same sources as the previous group. Similar are the questions to be answered: What are contemporary used alternative sources of energy? How many are they supposed to be in the Earth?; How much and often are they used globally and around you?; Do they exist any products of combustion from this type of sources?; What is their negative influence on the environment? The third group aims at a narrow topic - hydrogen drive of cars. Thanks to materials, especially from the Internet, the group should find answers to the following questions: What is a hydrogen fuel cell?; What are its advantages in comparison to traditional combustion engines?; Are there any disadvantages?; What are waste products when working?; In what way fuel cells are and can be used in industry and common life?

Having compiled all materials in groups, a presentation of them will be organized in the form of posters or using flipcharts, blackboard or other media. The following lesson will be devoted to laboratory activities with school model of „hydrogen-driven car” or with working sets of fuel cell models.

Laboratory activities with "Hydrogen-Driven Car":

1. Collecting the model from several parts according to the instruction.

2. Learning its single functions.

3. Explaining physical and chemical basis, writing down the chemical equations being in progress.

4. Explaining the term PEM.

5. Situating the solar panel to the source of solar energy. Following the development and speed of gases evolution depending on luminous intensity - creating graphs.

Having finished all laboratory activities, students should be able to answer following questions: What is the principle of "hydrogen-driven car" functioning? What is the source of hydrogen? What is the principle of PEM fuel cell? What is the difference of the types of fuel cells? How can hydrogen be stored? Characterize advantages and disadvantages. What are the chances to bring this type of electric car into common life? Characterize advantages and disadvantages.

Laboratory activities with student's set "Fuel Cells - Solar-Hydrogen Technology"

1. Collecting the model from several parts according to the instruction.

2. Learning its single functions.

3. Explaining the term PEM.

4. Explaining physical and chemical basis, writing down chemical equations being in progress.

5. Situating the solar panel to the source of solar energy. Following the development and speed of gases evolution depending on luminous intensity - creating graphs.

6. Monitoring activities of PEM electrolytic cell and PEM fuel cell.

7. Graphs monitoring delivered voltage depending on luminous intensity.

At finish students groups will present each other their results from the laboratory lesson. First of all similar functioning of single components in both model devices should be emphasised. The presentation and interpretation of recorded graphs should follow. A set of posters on topics Traditional Sources of Energy, Alternative Sources of energy, HydrogenDriven Car should form the project output. An Internet survey on how much car factories devote to development and projecting so called NECARs (BMW, Daimler/Chrysler, Ford...) supplemented by photos or examining whether either NECARs or NEBUSes are generally used could be a final project task (Figure 2). 


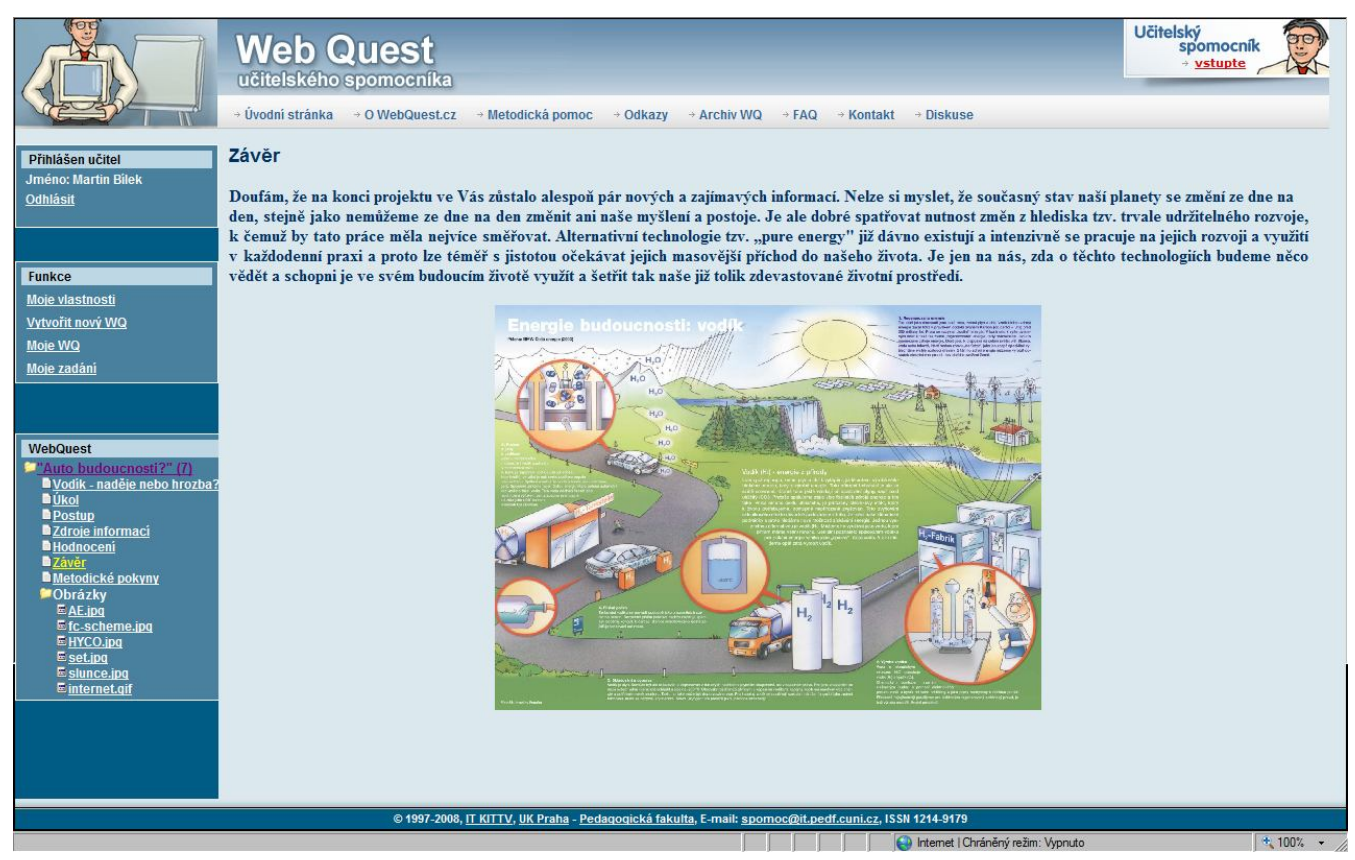

Figure 2. Finally page of the WebQuest "Car of the Future".

\section{Example of the Webquest - "Superabsorbents - amazing polymers"}

The proposal of the class project deals with studying structure, qualities and use of special polymers, so called ,superabsorbent polymers (SAP)“, which can be found e.g. in diapers (irreversible SAP), toys "Growing Beasts“ (reversible SAP) or other humidity absorbers. The aim of the project is to innovate students' laboratory activities and form their attitude to currently used materials and technologies. Activities with a molecule simulating set are followed by several experiments with SAP and toys "Growing Beasts“.

The project aims at:

- Getting information on polymers via active working - on the functioning, history, positive and negative influences when they are used in various fields of human activities,

- Innovating laboratory activities with SAP as products of everyday life,

- Contributing to gaining critical view on getting information and work with it, especially searching for information in professional literature, on the Internet etc.,

- Supporting creative students' activities, ability to present results of their work and active teamwork.

The introductory part of the students' Webquest-project will be devoted to creating teams (two teams), planning schedule of the tasks and discussions with the teacher. The task for first team is to define basic macromolecular chemistry terms and structure them. The necessary information will be gained from the library (studying professional literature), Internet and professional magazines. The questions below may work as a clue: What is it a macromolecular stuff, polymer?; What are other types of polymers?; What is the difference among polymer, oligomer and monomer?; What we can say about the reaction course in macromolecular stuff? The task for second team is to study basic structure of superabsorbent polymers and describe them. Sources for searching are the same as in the team one. The questions below may work as a clue: How can we structure special polymers?; What is the definition of superabsorbent 
polymers (SAP) and what are their features?; What is the widest and last field of the SAP use?; What are the advantages and disadvantages of the SAP use?; How is influenced the environment by the SAP?

Students prepare detailed materials on the topics mentioned above, partly during lessons; partly they study on their own. Having finished this phase, the results will be presented in lessons where members of both teams will participate. Preparing and presenting posters or editing down the results on the flipchart might be suitable ways of presentation.

The lessons following the theoretical part will be devoted to activities with molecular simulating set, i.e. building the SAP structure (set Molecular models). Then laboratory activities with superabsorbent polymers, i.e. with powdered SAP and toys on the basis of reversible superabsorbent polymers „Growing beasts“ will follow in two teams, it enables division of tasks.

In the finally lesson students each other present the results of their work. First of all the function of superabsorbent in relation to the human organism should be emphasized (the independence of the absorption speed on temperature, $\mathrm{pH}$ a $\mathrm{NaCl}$ water solution concentration). The presentation and interpretation of results in graphic should be necessary part. Last task is an Internet survey on searching for the firms in the Czech Republic, which deal with SAP production and in what extend, e.g. Degussa Krefeld, Kimberly-Clark etc., supported by photos from the firms and educational excursion.

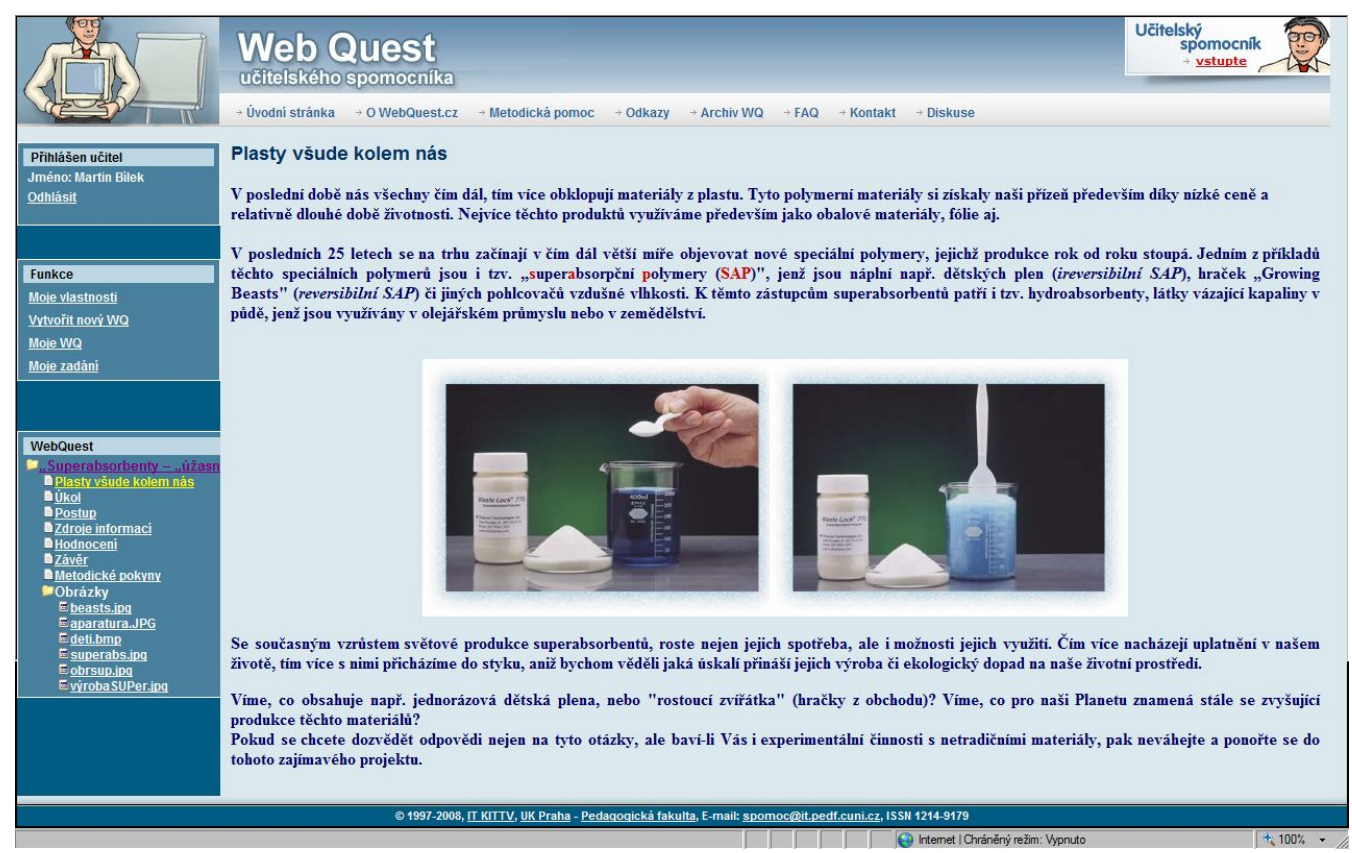

Figure 3. Introductory page of the WebQuest "Superabsorbents - amazing polymers".

\section{Conclusion}

The school projects assigned by the WebQuest environment aim at presenting a topic which can be taught and learned via new ways supported by the Internet - using links and references to search for new sources of information. The relation between the science and technical education and everyday life is often missing. This kind of project contributes to 
changing this negative situation considerably (Krumina, Bilek, Lakhvich, Sukhankina, 2008; Semrádová, 2003; Lamanauskas, Vilkonis, 2005).

\section{References}

Bílek, M., Ulrichová, M. (2006). WebQuest - Virtual Environment for Project Oriented Chemistry Education (in Czech). Chem. Listy, 100, 684-697.

Bílek, M.; Zemanová, M. (2007a). Methodical ways for Internet Using in Chemical Education (in Czech). In: Tóthová, A.; Veselský, M. (eds.): ScienEdu - Aktuálne trendy vo vyučovaní prírodovedných predmetov. Bratislava: PriF UK, p. $393-396$.

Bílek, M., Zemanová, M. (2007b). Internet in Chemistry Education at Basic School (In Czech). [online]. Hradec Králové: Gaudeamus, 2007 - [cit. 2005-11-03] Available from:

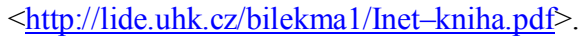

Krumina A., Bilek M., Lakhvich T., Sukhankina N. (2008). Towards Environmentally-friendly Teaching of Chemistry. Eco-Balt, $84-85$.

Lamanauskas, V., Vilkonis, R. (2005). Application of Computer Technologies ny NonGovermental Organization in Lithuania for Ecological Education of the Society. In: Bílek, M. (ed.): Internet in Science and Technical Education. Hradec Králové: Gaudeamus, pp. 53 - 58.

Nolte, M. (2005). WebQuest. Eine Handlungsorientirte Methode zum Interneteinsatz im Chemieunterricht. Unterricht Chemie, 16, Nr. 90, $554-557$.

Opatrný, P. (2007). On-line proposals of Class Natural Sciences Projects on Virtual Environment (in Czech). In: Alternativni metody výuky. Praha: PřF UK.

Semrádová, I. (2003). Paradigmas of Communication and Education Technology (In Czech).

Hradec Králové: Gaudeamus.

WebQuest [online]. (2005). Praha: Katedra informačních technologií a technické výchovy

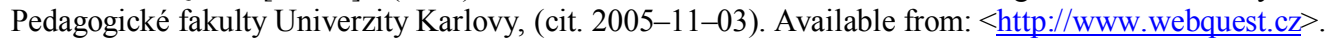

Received 12 August 2008; accepted 21 November 2008

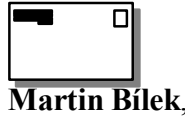

Department of Chemistry, Pedagogical Faculty, University of Hradec Králové

Rokitanského 62, 50003 Hradec Králové, Czech

Republic and

Department of Chemistry, Faculty of Natural

Sciences, Constantine the Philosopher University of Nitra, Tr. A. Hlinku 1, 47600 Nitra, Slovakia

E-mail: martin.bilek@uhk.cz

Website: $\underline{\text { http://www.uhk.cz/eng/ }}$

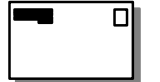

Pavel Opatrný

Department of Teaching and Didactics of Chemistry, Faculty of Science, Charles University in Prague, Albertov 3, 12000 Prague, Czech Republic and Department of Pedagogical Studies, Faculty of Humanities, Tomas Bata University in Zlin, nám. T. G. Masaryka 1279, 76001 Zlín, Czech Republic E-mail: opatrny@fhs.utb.cz Website: http://www.cuni.cz/UKENG-1.html 